\title{
El tratamiento jurídico de la ineficacia en la disposición unilateral de bienes de la sociedad conyugal a puertas del Octavo Pleno Casatorio Civil(")
}

\author{
The legal treatment of inefficiency in the unilateral disposition of goods \\ in the marital partnership at the gates of the Eighth Civil Cassation \\ Plenaries
}

\author{
Marja Ulanova Vargas Jiménez $\left.{ }^{(*)}\right)^{(+* *)}$ \\ Universidad Nacional de Piura
}

\begin{abstract}
Resumen: El tema objeto de investigación tiene como principal motivo analizar la consecuencia jurídica idónea en los actos de disposición o gravamen de bienes de la sociedad conyugal realizados por uno solo de los consortes que se encuentra inscrito en los Registros Públicos como si fuesen bienes propios de los cónyuges. Lo desarrollado en los debates a puertas de emitir el Octavo Pleno Casatorio Civil, es importante para establecer si el remedio jurídico es la nulidad o ineficacia del negocio jurídico celebrado por el cónyuge que no cuenta con un poder especial del otro consorte para representar a la sociedad.
\end{abstract}

Palabras Claves: Octavo Pleno Casatorio Civil - Negocio Jurídico - Sociedad Conyugal- Disposición de Bienes Sociales - Nulidad - Invalidez - Ineficacia - Interés Familiar.

Abstract: The main object of this research is to analyze the ideal legal
consequence in the acts of disposition or encumbrance of property of the
marital partnership carried out by one of the consorts who is registered in
the Public Records as if they were property of the conjugal. Developed in
the debates at the gates of issuing the Eighth Civil Cassation Plenaries, it is

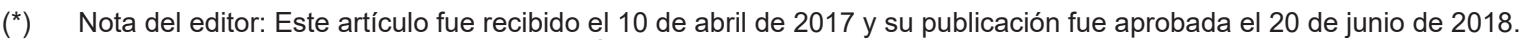

${ }^{(* *}$ Abogada por la Universidad Católica Los Ángeles de Chimbote. Magíster en Derecho Civil y Comercial por la Universidad Nacional de Piura. Defensora Municipal de la Municipalidad Provincial de Piura. Membrecía del llustre Colegio de Abogados de Piura. Correo electrónico: calandria25@gmail.com

${ }^{* * *}$ En colaboración con Jorge Enrique Junior Del Valle Müller Vargas. Estudiante del doceavo ciclo de la Facultad de Derecho de la Pontificia Universidad Católica del Perú. Parlamentario Joven Nacional 2017- 2018 por Piura. Miembro de la Comisión de Publicaciones de la Asociación Civil IUS ET VERITAS. Asistente de Docencia del curso Contratos Típicos en la PUCP. Correo electrónico: a20165963@pucp.edu.pe 


\author{
El tratamiento jurídico de la ineficacia en la disposición unilateral de bienes de la sociedad conyugal \\ a puertas del Octavo Pleno Casatorio Civil \\ The legal treatment of inefficiency in the unilateral disposition of goods in the marital partnership at \\ the gates of the Eighth Civil Cassation Plenaries
}

important to establish if the legal remedy is the nullity or inefficacy of the legal business held by the spouse who does not have a special power of the other consort to represent society.

Keywords: Eighth Civil Cassation Plenaries - The Business of Law - Marital Partnership- Social Property - Nullity - Invalidity Inefficiency - Family Interest.

Sumario: 1. Introducción_2. La constitución de los negocios jurídicos en el ordenamiento jurídico peruano_3. La sociedad de gananciales y los actos de disposición de bienes sociales_4. La teoría de la nulidad como remedio en la sociedad de gananciales_ 4.1. En la doctrina_4.2. En la jurisprudencia_5. La tesis de la ineficacia como remedio jurídico conveniente a puertas del Octavo Plano Casatorio_6. Conclusiones_7. Referencias Bibliográficas.

\section{Introducción}

Los Magistrados Civiles de la Corte Suprema de la República se reunieron el pasado 22 de diciembre de 2015 en el Palacio de Justicia para debatir el sentido en que ha de resolverse el VIII Pleno Casatorio (Diario Oficial El Peruano 2015), el mismo que deberá definir si la disposición unilateral, es decir, de uno de los cónyuges sobre bienes conyugales en régimen de sociedad de gananciales es nulo (Castillo y Martín 2002,40) o ineficaz en sentido estricto(1) (Morales $2005,101)$ (en adelante solo ineficacia) si este carece de poder especial que lo faculte a realizar tal disposición o en caso de que el otro cónyuge no intervenga en dicho negocio jurídico, teniendo en consideración que registralmente ${ }^{(2)}$ el bien social(3)(4) figura a nombre de quien realizó el acto de disposición en los Registros Públicos.

Para los fines del debate, los Magistrados convocaron a cinco amicus curiae (Defensoría del Pueblo 2009,18) a la sesión realizada con el propósito de ilustrar con puntos de vista variopintos las distintas posiciones jurídicas existentes en la doctrina acerca del tan controversial tema puesto a su conocimiento. Sus planteamientos han aportado nuevas luces a la Sala que permitirán la obtención de una resolución adecuada al proceso (CSJR 2015) materia de controversia conforme a la realidad, a la naturaleza de las figuras jurídicas en discusión y a las necesidades proteccionistas del patrimonio familiar que la sociedad reclama y el ordenamiento tutelar

(1) La doctrina actual permite afirmar que la ineficacia es una noción muy amplia. Se trata de una concepción que abarca a todas las patologías y vicios que atacan a los negocios jurídicos, es decir, nulidad, anulabilidad, resolución, recisión, etc. Es por ello por lo que es conveniente indicar que a la ineficacia a la que nos referimos es a la en sentido estricto, que es la no producción de los efectos esperados por las partes de un negocio jurídico válido.

(2) Artículo $2013^{\circ}$ del Código Civil. - "El contenido de la inscripción se presume cierto y produce todos sus efectos, mientras no se rectifique o se declare judicialmente su invalidez".

(3) Artículo $310^{\circ}$ del Código Civil. - "Son bienes sociales todos los no comprendidos en el artículo 302, incluso los que cualquiera de los cónyuges adquiera por su trabajo, industria o profesión; así como los frutos y productos de todos los bienes propios y de la sociedad y las rentas de los derechos de autor e inventor. También tienen la calidad de bienes sociales los edificios construidos a costa del caudal social en suelo propio de uno de los cónyuges, abonándose a este el valor del suelo al momento del reembolso".

(4) Artículo $302^{\circ}$ del Código Civil. - "Son bienes propios de cada cónyuge: 1 .- Los que aporte al iniciarse el régimen de sociedad de gananciales. 2.- Los que adquiera durante la vigencia de dicho régimen a título oneroso, cuando la causa de adquisición ha precedido a aquella. 3.- Los que adquiera durante la vigencia del régimen a título gratuito. 4.- La indemnización por accidentes o por seguros de vida, de daños personales o de enfermedades, deducidas las primas pagadas con bienes de la sociedad. 5.- Los derechos de autor e inventor. 6.- Los libros, instrumentos y útiles para el ejercicio de la profesión o trabajo, salvo que sean accesorios de una empresa que no tenga la calidad de bien propio. 7.- Las acciones y las participaciones de sociedades que se distribuyan gratuitamente entre los socios por revaluación del patrimonio social, cuando esas acciones o participaciones sean bien propio. 8.- La renta vitalicia a título gratuito y la convenida a título oneroso cuando la contraprestación constituye bien propio. 9.- Los vestidos y objetos de uso personal, así como los diplomas, condecoraciones, correspondencia y recuerdos de familia." 
Marja Vargas

por ser el sostén material del hogar (Jara y Gallegos 2011, 143). Cabe resaltar que la solución a la que arriben los Jueces será vinculante ${ }^{(5)}$ para las futuras resoluciones que se emitan en casos similares en donde se ponga a conocimiento de los tribunales un supuesto hecho amparado y regulado por el artículo $315^{\circ}$ del Código Civil vigente ${ }^{(6)}$.

La discusión que llevará a analizar los alcances del artículo $315^{\circ}$ del Código Civil vigente hizo concurrir en una prolongada sesión a diferentes juristas peruanos expertos en materia de Derecho Civil. Dentro de los amigos del tribunal que acudieron a esa jornada tenemos a Álex Plácido Vilcachagua, Enrique Varsi Rospigliosi, Gastón Fernández Cruz, Giovanni Priori Posada y Rómulo Morales Hervias. Cabe destacar que este llamamiento que hace el Tribunal a sus "amigos" se ha convertido en una práctica idónea para ampliar la perspectiva jurídica de los Magistrados sobre la materia que les permita resolver un caso de forma precisa y certera.

Cada uno de estos profesores vierte en sus postulados los posibles alcances y consecuencias jurídicas que le corresponde al acto de disposición de bienes de la sociedad conyugal que ha sido realizado por solo uno de ellos, supuesto no previsto por el artículo mencionado del Código Civil. Si bien, cada jurista defiende sus distintos planteamientos ${ }^{(7)}$, basados en las distintas teorías acerca de este particular caso de disposición de bienes sociales, a nuestro juicio de esta discusión, destacan los postulados de la nulidad y la ineficacia, ambas fundadas en la ausencia de manifestación de voluntad del cónyuge no interviniente en el acto de disposición.

Con el objetivo de uniformizar(8) (CSJR 2015) la consecuencia jurídica de la disposición de bienes sociales unilateralmente; recogida y regulada en el ordenamiento jurídico peruano en el Libro III del Código Civil, y a fin de evitar futuros debates doctrinales y jurisprudenciales respecto al tema, el Octavo Pleno Casatorio pretende establecer con su próxima decisión, el remedio jurídico más adecuado para este tipo de negocio jurídico celebrado.

Se pretende con esta futura sentencia hallar una consecuencia jurídica garantista que proteja eficazmente a la sociedad conyugal (Espinoza 2001, 22) ${ }^{(9)}$ frente a los efectos del negocio dispositivo que pudiesen recaer en su esfera jurídica, de la cual es parte (CSJR 1999), fruto del matrimonio, el cónyuge desconocedor de los actos que realiza su consorte. En consecuencia, le son inoponibles al cónyuge inocente los efectos de ese negocio

(5) Artículo $400^{\circ}$ del Código Procesal Civil. - "La Sala Suprema Civil puede convocar al pleno de los magistrados supremos civiles a efectos de emitir sentencia que constituya o varíe un precedente judicial. La decisión que se tome en mayoría absoluta de los asistentes al pleno Casatorio constituye precedente judicial y vincula a los órganos jurisdiccionales de la República, hasta que sea modificada por otro precedente. Los abogados podrán informar oralmente en la vista de la causa, ante el pleno Casatorio. El texto íntegro de todas las sentencias casatorias y las resoluciones que declaran improcedente el recurso se publican obligatoriamente en el Diario Oficial, aunque no establezcan precedente. La publicación se hace dentro de los sesenta días de expedidas, bajo responsabilidad ".

(6) Artículo $315^{\circ}$ del Código Civil. - "Para disponer de los bienes sociales o gravarlos, se requiere la intervención del marido y la mujer. Empero, cualquiera de ellos puede ejercitar tal facultad, si tiene poder especial del otro. Lo dispuesto en el párrafo anterior no rige para los actos de adquisición de bienes muebles, los cuales pueden ser efectuados por cualquiera de los cónyuges. Tampoco rige en los casos considerados en las leyes especiales".

(7) Vídeo de participación en el VIII Pleno Casatorio Civil de la Corte Suprema de la República la participación de los amicus curiae. Consulta: 27 de junio de 2017. <https://www.youtube.com/watch?v=E0e1cABGMNA>

(8) Se pretende homogeneizar la solución que se le brinde en estos casos en concreto debido a que de forma repetida y prologada los jueces peruanos, desde un juez civil de primera instancia hasta los Magistrados de la Corte Suprema, resuelven con criterios dispares e incluso contradictorios al decantarse entre nulidad o la ineficacia.

(9) Artículo 57 del Código Procesal Civil. - "Toda persona natural o jurídica, los órganos constitucionales autónomos y la sociedad conyugal, la sucesión indivisa y otras formas de patrimonio autónomo, pueden ser parte material en un proceso". Al ser un patrimonio autónomo es un centro de imputación de derechos y deberes. 
El tratamiento jurídico de la ineficacia en la disposición unilateral de bienes de la sociedad conyugal a puertas del Octavo Pleno Casatorio Civil

The legal treatment of inefficiency in the unilateral disposition of goods in the marital partnership at the gates of the Eighth Civil Cassation Plenaries

jurídico, pues al ser parte de la sociedad, requiere de su consentimiento para que dicho acto le sea eficaz. Con ello, se tutela al cónyuge lesionado de cualquier efecto jurídico indeseado que pudiese recaer en la esfera jurídica de la sociedad que pudiera tornarse gravoso y generarle un perjuicio a la sociedad en aras de proteger la integridad patrimonial de la esfera jurídica de esa entidad de la que son cotitulares ambos cónyuges. Es por ello por lo que el ordenamiento exige que para la disposición de los bienes que sustentan la manifestación de voluntad aprobatoria de ambos esposos ya que son aquellos ${ }^{(10)}$ quienes representan legítimamente la sociedad conyugal.

El objetivo de este trabajo es mostrar en las líneas siguientes una breve perspectiva de la situación actual del tema materia de este artículo desde el punto de vista de la doctrina nacional y de la jurisprudencia, en vísperas a la emisión de la resolución de este proceso judicial, que tendrá el carácter de Acuerdo Plenario y que será recogido en el Octavo Pleno Casatorio. Acto seguido, abordaremos el análisis jurídico de esta controversia desde la perspectiva de la ineficacia debido a que la consideramos como la consecuencia jurídica idónea frente a este tipo de actos de disposición unilaterales de bienes sociales. Es menester hacer hincapié que, las líneas subsiguientes se enfocarán únicamente en el análisis de la materia desde la perspectiva de la relación jurídico- patrimonial entre cónyuges, dejándose de lado para el propósito de este trabajo el análisis de las relaciones jurídicas generadas con los terceros fruto de este negocio de transferencia.

Para nuestro estudio, tomaremos como puntos de referencia lo aportado tanto por la doctrina y la jurisprudencia de la nulidad defendida en el mundo académico por Álex Plácido, así como por la doctrina de la ineficacia preservada por Rómulo Morales Hervias, Giovanni Priori, Enrique Varsi, entre otros y por un cierto sector de la jurisprudencia que ha optado por seguir esta corriente de pensamiento al momento de establecer los fundamentos jurídicos y los mandatos de sus sentencias.

Es por ello por lo que consideramos indispensable esclarecer la naturaleza de la institución civil de la ineficacia, la cual nos permitirá comprender por qué es esta la consecuencia jurídica más adecuada en la interpretación del artículo $315^{\circ}$ del Decreto Legislativo $N^{\circ} 295$ a nuestro juicio, basándonos en lo dicho por la doctrina y jurisprudencia nacional.

Para concluir este apartado, es relevante mencionar que, sin lugar a duda, la resolución a la que arriben los Magistrados importará un significativo avance en el proceso de tutela de los intereses conyugales, especialmente los de la sociedad de gananciales en nuestro ordenamiento jurídico. Con esta decisión no solo se homogeneizará el criterio con el que ha de entenderse la consecuencia jurídica del artículo $315^{\circ}$ del Código Civil en caso de disposición unilateral de bienes de la sociedad de gananciales, sino que permitirá salvaguardar los derechos del cónyuge perjudicado en tanto que no se le harán eficaces a aquel los efectos de este acto realizado por su consorte sin que haya mediado la concurrencia de las voluntades de ambos cónyuges al realizar la disposición de bienes de la sociedad conyugal. En otras palabras, solo si concurren ambas voluntades conyugales, entonces el acto es válido y eficaz respecto a ambos cónyuges, sin embargo, si tan sólo existe una sola voluntad, el acto es válido, pero ineficaz respecto al cónyuge que no manifestó su voluntad.

\section{La constitución de los negocios jurídicos en el ordenamiento jurídico peruano}

El negocio jurídico es una de las instituciones fundamentales del Derecho Civil por ser la principal fuente generadora de vínculos y efectos jurídicos entre quienes manifiestan su libre actitud negocial de relacionarse con otras personas para satisfacer su interés. Sin

(10) Art. 65 del Código Procesal Civil. - “(...) La sociedad conyugal y otros patrimonios autónomos son representados por cualquiera de sus partícipes (...)." 
Marja Vargas

embargo, muchas son las definiciones presentes en la doctrina del negocio jurídico que pretenden explicar su naturaleza y contenido, empero, para efectos de este artículo hemos optado por la definición voluntarista (Sconamiglio 2004, 4), la cual que nos parece más apropiada por ser la que coincide con la definición original de esta figura jurídica. Esta es la que nos brinda el jurista Savigny $(1878,213)$. En nuestro país, uno de los jurisconsultos que ha continuado con los planteamientos savignianos es Leysser León. La definición de negocio jurídico con la que nosotros trabajaremos es la que él nos proporciona por ser no solo la que más se adapta a nuestra realidad jurídica desde nuestro juicio, sino que desarrolla la definición primigenia de esta institución del Derecho Civil que cobra relevancia en el presente análisis. Para él, el negocio jurídico es la libre manifestación de una voluntad (Stolfi 1959, 1) negocial destinada crear y extinguir relaciones jurídicas negociales entre dos o más sujetos que se vinculan y cuya actuación va a producir efectos jurídicos (León, 2014, 34). De ello se obtiene que de esta relación jurídica sean las partes las que en ejercicio de su autonomía de la voluntad regulan (Betti $2000,51)$ y reglamentan sus propios intereses produciéndose entre las partes normas jurídicas (Morales 2007, 293-298) de obligatorio cumplimiento, satisfaciendo en esta relación sus propias necesidades privadas (Taboada 1992, 56).

Desarrollada la definición adecuada de un negocio jurídico, paso seguido corresponde trabajar cómo se da la conformación de los negocios jurídicos en el sistema jurídico peruano.

Un negocio jurídico que se forma y desenvuelve perfectamente, permite a las partes alcanzar la finalidad para el que ha sido creado. Sin embargo, determinar si un negocio cumple con los requisitos que lo hacen óptimo es una tarea compleja ya que tiene que ser evaluado necesariamente en tres etapas sucesivas y cancelatorias (Pontes de Miranda 1954, 6-7). Es decir, para ser pleno y óptimo, el negocio jurídico debe superar tres niveles de manera obligatoria. Estas cotas de superación son la existencia, la validez y la eficacia; teniendo cada una su propia naturaleza y consecuencia jurídica distinta. La existencia o ser (Albaladejo 1958, 396) de un negocio jurídico en la realidad dependen de la presencia de aquellos elementos que lo componen (De Castro Bravo 1985, 463-465) (11) y que nos permitan identificar su presencia, de lo contrario, este devendría en inexistente (Montiel 2003, 95). Los elementos que lo hacen existente son el sujeto, la manifestación de voluntad, el objeto, la causa y la forma solemne. De estar ausente uno de ellos, se configura la inexistencia, la cual es una patología irreparable del negocio jurídico que origina su muerte e ineficacia.

De existir el negocio en la realidad, podemos ir al siguiente escalón que es la validez. Esto implica que, además de la existencia del negocio, los componentes de este, sus cualidades y demás requisitos que establece el ordenamiento jurídico deben presentarse desde su constitución (García 2005, 318) para que el negocio sea en su integridad conforme a las normas que el ordenamiento establece (Rubio 2003, 15). De ser así, el negocio es válido y existe. En sentido contrario, de no cumplirse con estas características de validez, el negocio es inválido. La invalidez configura otro defecto del negocio jurídico. Frente a dicho defecto, dos consecuencias jurídicas son posibles, la nulidad o la anulabilidad(12). Dependiendo de las causales establecidas en la norma en que haya incurrido el negocio será declarada la una o la otra. Para efectos de este trabajo, nos enfocaremos únicamente en

(11) Art 140 del Código Civil. - (...) Para su validez se requiere: 1.- Agente capaz.2.- Objeto física y jurídicamente posible.3.- Fin lícito.4.- Observancia de la forma prescrita bajo sanción de nulidad.

(12) Artículo 221 del Código Civil. -

1. Por incapacidad relativa del agente.

2. Por vicio resultante de error, dolo, violencia o intimidación.

3. Por simulación, cuando el acto real que lo contiene perjudica el derecho de tercero.

4. Cuando la ley lo declara anulable. 
El tratamiento jurídico de la ineficacia en la disposición unilateral de bienes de la sociedad conyugal a puertas del Octavo Pleno Casatorio Civil

The legal treatment of inefficiency in the unilateral disposition of goods in the marital partnership at the gates of the Eighth Civil Cassation Plenaries

la nulidad cuyas causales están reguladas en el artículo $219^{\circ}$ del Código Civil(13), lo que implica que, de incurrir en alguna de ellas, el negocio es insubsanable, y, por lo tanto, no producirá efecto jurídico alguno de los acordados entre las partes.

El tercer y último paso es la eficacia, es decir, si el negocio produce efectos jurídicos. De cumplir con los dos pasos anteriores, los efectos deben surgir de manera instantánea, satisfaciendo los intereses que llevaron a las partes a realizar un negocio jurídico (Rubio 2003, 11-13).

El Derecho siempre exige la existencia de creatividad entre la tipicidad que describe la norma y la realidad negocial, sin embargo, esto a veces no se presenta. Esta discrepancia implica una violación a la norma jurídica. De esta forma surge la ineficacia, como una reacción, como una sanción del ordenamiento frente a esta infracción, que conlleva a la no producción de los resultados esperados por las partes.

Es por ello por lo que existen supuestos en que los negocios jurídicos no surten efectos automáticamente. Es decir, el negocio existe, es válido, pero es ineficaz (Canales 2007, 102-104). Por ende, el negocio cae en una tercera patología, la ineficacia. Esta puede ser causada por causas externas al negocio (Torres 1998, 573-574) o porque la ley ha estipulado un requisito que debe ser cumplido antes de la producción de efectos o deja de producir efectos, esto es, causas sobrevinientes (Taboada 2002, 297-298) a la celebración del negocio jurídico.

Una de las causales externas más relevante para efectos de esta investigación es la ausencia de legitimidad para realizar un negocio jurídico, también conocido como falso representante, dentro de la que encuadra el negocio jurídico realizado por solo uno de los consortes sin consentimiento (Vásquez 2016) del otro (Morales 2016, 309-311). Este es un ejemplo de ineficacia temporal o transitoria, es decir, por un tiempo no produce efectos, pero en el futuro puede cobrar eficacia si este es confirmado. Los negocios realizados por el aparente representante son inoponibles e ineficaces (Morales 2013, 14-20) frente al representado, es decir, no produce efectos frente al que se perjudica debido a que quien dispone de los bienes no posee legitimidad para realizar dichos actos de disposición de una esfera jurídica que no es la suya, a menos que al cabo de un tiempo este lo confirme.

La ineficacia como tal puede ser enmendada o puede pedir en cualquier momento que esta sea declarada judicialmente. Un negocio ineficaz por falta de legitimidad puede volverse eficaz siempre que este sea confirmado posteriormente por el aparente representado de forma unilateral (Roppo 2009, 282-284). Asimismo, el ordenamiento le reserva la protección al afectado de pedir la ineficacia del negocio jurídico afectado por esta patología en cualquier momento, en la medida que el ordenamiento no ha establecido un plazo de prescripción que limite al mismo a ejercer su acción de ineficacia.

\section{La sociedad de gananciales y los actos de disposición de bienes sociales}

La familia, como un ente nuclear de la sociedad, requiere para realizar sus fines de medios económicos que permitan alcanzarlos. Para

(13) Artículo 219 del Código Civil. -

1. Cuando falta la manifestación de voluntad del agente.

2. Cuando se haya practicado por persona absolutamente incapaz, salvo lo dispuesto en el artículo $1358^{\circ}$.

3. Cuando su objeto es física o jurídicamente imposible o cuando sea indeterminable.

4. Cuando su fin sea ilícito.

5. Cuando adolezca de simulación absoluta.

6. Cuando no revista la forma prescrita bajo sanción de nulidad.

7. Cuando la ley lo declara nulo.

8. En el caso del artículo V del Título Preliminar, salvo que la ley establezca sanción diversa". 
Marja Vargas

ello, es necesario que esta cuente con un patrimonio familiar que garantice la subsistencia de la familia, la satisfacción de sus necesidades básicas y el cumplimiento de los derechos y deberes a los que se sujeta (Jara y gallegos 2011, 143-144). La conformación de este patrimonio familiar tiene su origen en la unión de los cónyuges a través del matrimonio. Ambos cónyuges, tras el casamiento, se sujetan a una diversidad de normas jurídicas que van a regular sus relaciones jurídicopatrimoniales, ya sea entre ellos o con terceros. A este conjunto de normas que regulan las mencionadas relaciones se les conoce como régimen patrimonial matrimonial. Dicho régimen fija las pautas acerca de cómo el patrimonio propio de los esposos contribuirá a la formación del patrimonio familiar. De igual forma, regulan los aspectos relativos a la propiedad de los bienes dentro del matrimonio, así como lo relativo a la administración de los bienes que integran aquel patrimonio durante la subsistencia del vínculo conyugal. Cabe resalta que son estos bienes los que satisfacen los intereses de los esposos (Jara y Gallegos 2011, 144-146). En función al artículo $295^{\circ}$ del Código Civil, en su primer párrafo, previo a la celebración del matrimonio, los futuros contrayentes pueden optar de forma libre por el régimen de sociedad de gananciales o por el de separación de patrimonios, el cual empezará a surtir efectos tras la celebración del matrimonio. De no acordarse un régimen de separación patrimonial, la ley presume que el matrimonio se contrae bajo el régimen de la sociedad de gananciales.

La sociedad de gananciales es un patrimonio, común, indivisible (CSJR 2006) (La Cruz Berdejo 1950, 38), es decir, inexistente de derechos de cada individuo que aportó para su formación, autónomo que la distingue de sus miembros que tienen un derecho o interés ${ }^{(14)}$ común respecto de los bienes sociales, sui generis e integrado por un universo de bienes destinado a satisfacer las necesidades familiares que tiene su origen legal fruto de la celebración del matrimonio. Las aportaciones de los cónyuges a la sociedad forman un capital social de propiedad colectiva que le pertenece al sujeto de derecho formado tras el matrimonio, esto es, la sociedad conyugal. Es la comunidad de bienes entre marido y mujer que les permitirá generar beneficios o asumir deudas contraídas por la sociedad en beneficio de la familia. La sociedad de gananciales no es una persona jurídica y siempre los titulares de los bienes, de este patrimonio en común que forma una unidad, son los dos consortes.

Los bienes de la sociedad de gananciales solo pueden ser dispuestos y administrados de forma mancomunada por los cónyuges, esto es, la sociedad conyugal. Es un patrimonio que no está dividido en partes alícuotas, es decir, es un solo derecho real, que es propio de la figura jurídica de la copropiedad o condominio, y son distintos de los patrimonios de cada cónyuge (De la Puente 1999, 52). De esta forma, para realizar actos de disposición como de administración que recaigan sobre bienes de la sociedad será indispensable la voluntad de ambos consortes ya que esta voluntad coincidente de los esposos constituye en sí la voluntad de la sociedad conyugal. Estos bienes sociales gozan del carácter de pertenencia que tiene la sociedad conyugal (Zegarra 2009,70), la cual se encuentra especialmente protegida en cuanto son el sustrato material de la familia, es decir, son de propiedad de la sociedad hasta que esta se disuelva o sean dispuestos por voluntad de ella misma.

Los actos de administración de la sociedad conyugal les corresponden a ambos consortes, sin embargo, tomando en consideración lo dispuesto por el artículo $292^{\circ}$ del Código Civil, la sociedad puede ser representada sin distinción por cualquiera de los esposos siempre que verse sobre actos de administración ordinaria de la sociedad, es decir, sobre las necesidades ordinarias de la familia y la preservación de su patrimonio. Por lo tanto, se necesita la actuación conjunta de ambos consortes sobre actos de administración o de disposición que sobrepasan los actos ordinarios de la familia

(14) Artículo 65 C.P.C. Existe patrimonio autónomo cuando dos o más personas tienen un derecho o interés en común respecto de un bien, sin constituir una persona jurídica (...). 
El tratamiento jurídico de la ineficacia en la disposición unilateral de bienes de la sociedad conyugal a puertas del Octavo Pleno Casatorio Civil

The legal treatment of inefficiency in the unilateral disposition of goods in the marital partnership at the gates of the Eighth Civil Cassation Plenaries

puesto que se procura salvaguardar, tutelar y garantizar el interés de la familia y su soporte económico frente al peligro de actos que disminuyan su integridad (Plácido 2005, 330-331).

Empero, el sistema jurídico admite la posibilidad de delegarse el poder de representación entre los cónyuges para que solo uno de ellos ejerza exclusivamente la administración de los bienes sociales, debiendo indemnizar al otro por los daños que eventualmente le ocasione por su mala administración, ello en concordancia con el artículo $313^{\circ}$ del Código Civil vigente ${ }^{(15)}$.

El ordenamiento al tutelar los supuestos de disposición y gravamen de bienes sociales que la sociedad conyugal desee realizar exige para transportar un bien, de la esfera jurídica de la sociedad conyugal a otra situación jurídica, la realización de uno o más actos de disposición (Moisés de Espanés 1972) válidos que expresen la voluntad dispositiva negocial y administrativa de la sociedad. En consciencia, un acto de disposición de bienes pleno-sociales es un negocio jurídico a través del cual se transfieren válida y eficazmente bienes, entendidos estos como cosas o derechos, creando y extinguiendo de nuevas relaciones jurídicas y modificando la situación jurídica y patrimonial de quien realiza el acto de disposición y a quien le afecta.

Al ser un negocio jurídico, es susceptible de poseer patologías previamente trabajadas que rompan su fortaleza y su perfeccionamiento, en especial las de nulidad e ineficacia. Normalmente, un bien encuentra como medio idóneo para su disposición el contrato (Bullard 1993, 92) ya que es la figura que permite las transferencias de bienes de una esfera jurídica a otra dada la rapidez de los negocios y la agilidad que se requiere para ellos. Este acto de disposición de bienes no es la excepción dado que el contrato es la figura que abarca la gran mayoría de estos actos de transferencia de bienes a los que nos indica el artículo $315^{\circ}$ del Código Civil. Requiere de este medio para una válida y eficaz transmisión de patrimonio. Para conseguir esa finalidad traslativa de bienes, la ley exige la intervención de ambos cónyuges para que dicho negocio sea saludable. Sin embargo, si la transmisión patrimonial de bienes de la sociedad de gananciales se produce de manera unilateral, es decir, ignorando el otro cónyuge de la realización de este negocio, nos encontramos frente al escenario que el artículo $315^{\circ}$ del Código Civil no nos ofrece una respuesta clara y mucho menos la doctrina ni la jurisprudencia, que en especial estas dos últimas son tan variadas respecto a la consecuencia jurídica idónea que debería recibir este negocio celebrado. Cierto sector de la doctrina y la jurisprudencia afirma que debería ser la nulidad, sin embargo, otro sector defiende la tesis de ineficacia. La idoneidad de la solución que se utilice dependerá de la comprensión de los planos del negocio jurídico y el análisis que se haga de ellos, en concordancia, con las exigencias de la realidad jurídica.

\section{La teoría de la nulidad como remedio en la sociedad de gananciales}

\subsection{En la doctrina}

La tesis de la nulidad, apoyada por un sector de la doctrina y cuyo referente dentro de los amicus curiae anteriormente mencionados es Álex Plácido Vilcachagua, propone ${ }^{(16)}$ que por falta de manifestación de voluntad (Taboada 1988, 71) en el negocio jurídico de disposición por parte de uno de los cónyuges de una sociedad conyugal acarrea la nulidad ${ }^{(17)}$ por ser un elemento esencial de validez del negocio jurídico. De igual forma, sostienen que el objeto es imposible jurídicamente, en

(15) Art. 313 del Código Civil. - "Corresponde a ambos cónyuges la administración del patrimonio social. Sin embargo, cualquiera de ellos puede facultar al otro para que asuma exclusivamente dicha administración respecto de todos o de algunos de los bienes. En este caso, el cónyuge administrador indemnizará al otro por los daños y perjuicios que sufra a consecuencia de los daños y perjuicios que sufra a consecuencia de actos dolosos y culposos."

(16) Vídeo de participación en el VIII Pleno Casatorio Civil de la Corte Suprema de la República la participación de los amicus curiae. Consulta: 27 de junio de 2017. <https://www.youtube.com/watch?v=E0e1cABGMNA>

(17) Inciso 1 del artículo 219 del Código Civil. 


\section{Marja Vargas}

función al artículo $315^{\circ}$ del Código Civil, debido a que la ley dictamina que para disponer bien conyugales se necesita el consentimiento de ambos consortes. Adicionalmente, el falso procurador, al realizar un ejercicio abusivo del poder de representación, produce en el negocio una patología de invalidez que acarrea la nulidad según el artículo II del Título Preliminar del Código Civil vigente ya que, según los principios generales del derecho, el ordenamiento no ampara el abuso del derecho. Para finalizar, señalan también la presencia de nulidad por incurrirse en una supuesta ilicitud del fin del negocio jurídico (Taboada 1988, 74), argumentando la eventual existencia de una voluntad de engañar y perjudicar al cónyuge que ignora los actos de su consorte. Esto se desprende en concordancia con el inciso $4^{\circ}$ del artículo $219^{\circ}$ del referido cuerpo normativo. Asimismo, precisan que la sanción que el artículo $315^{\circ}$ emana no puede ser de ningún modo la anulabilidad (Espinoza 2008, 482-485) ya que ello debe haber sido establecido de manera expresa por el ordenamiento civil.

En contra de las hipótesis vertidas en el párrafo anterior, consideramos que la falta de manifestación de voluntad -que alegan quienes defienden la tesis de la nulidad- evidentemente, como patología, debe recaer, como es lógico, en las partes del contrato de disposición, y no en lo relativo a la relación con un tercero que se vincula a través de este contrato, el cual, de por sí, es ajeno a esta relación contractual y carece de dominio sobre la situación jurídica. Con relación a lo anterior, y para los fines de este trabajo, la sociedad conyugal ha de ser entendida como aquel tercero al que nos hemos referido. Esta línea de pensamiento, a nuestro entendimiento, es la compartida por Gastón Fernández Cruz en su participación dentro de la sesión llevaba a cabo durante el VIII Pleno Casatorio Civil.

Frente al argumento de imposibilidad jurídica del objeto, nosotros alegamos que el negocio jurídico celebrado por el faso procurador recae sobre un objeto que es jurídicamente posible ya que, en principio, dispone de un bien social sobre el cual tiene derechos debido a que es parte junto a su consorte de la sociedad. En otras palabras, se dispone de un bien jurídicamente posible sobre el que se tiene derechos sociales. Y sobre el pretendido ejercicio abusivo realizado por el falso representante, debemos aclarar que ordenamiento jurídico permite expresamente la actuación "excesiva" de determinados agentes al momento del celebrar un negocio jurídico de bienes sobre los que no se tiene titularidad. Un ejemplo muy claro de ello es la contratación sobre bienes ajenos en el artículo $1537^{\circ}$ del Código Civil comúnmente conocida como compraventa de bien ajeno (Pozo 2016, 25), la cual permite la celebración de negocios jurídicos sobre bienes que no le pertenecen a ninguno de los contratantes al momento de celebrar un contrato. Estos son algunos lineamientos compartidos por Rómulo Morales Hervias en su presentación en la sesión de amicus curiae del referido pleno.

A nuestro entender, esta teoría confunde los planos de la validez con la eficacia, es decir, la correcta constitución del negocio jurídico con los efectos del negocio jurídico que este produce. Si se precisa que el negocio no es válido desde su constitución, por ende, incurre en una patología del negocio que causa la nulidad. Como consecuencia, este negocio es insubsanable a perpetuidad.

Como hemos dicho, la nulidad, como consecuencia jurídica natural frente a una patología del negocio jurídico presente en el escalón de la invalidez, únicamente puede ser invocada en los supuestos previstos en el artículo $219^{\circ}$ del Código Civil y en otros que la ley establezca como requisitos de validez. La nulidad es la sanción más grave que existe en el ordenamiento jurídico, es una consecuencia indeseable tanto para las partes contratantes, quienes no van a ver satisfechos sus intereses debido a que se le declarará muerto a ese negocio jurídico celebrado por las partes que nació fenecido, como al cónyuge que no participó (Morales 2011, 204-206).

De considerarse la nulidad como remedio jurídico frente a un acto de disposición de bienes de la sociedad de gananciales, se excluiría absolutamente la posibilidad de que mediante un acto posterior el cónyuge no interviniente manifieste su voluntad unilateralmente confirmando el negocio de disposición que en un inicio no participó. La normativa no exige que la concurrencia 


\section{El tratamiento jurídico de la ineficacia en la disposición unilateral de bienes de la sociedad conyugal a puertas del Octavo Pleno Casatorio Civil}

The legal treatment of inefficiency in the unilateral disposition of goods in the marital partnership at the gates of the Eighth Civil Cassation Plenaries

de voluntades de disponer el bien social se dé al mismo tiempo, por lo que es perfectamente válido y eficaz que la manifestación de voluntad de confirmación o aceptación a ese negocio se dé en un momento posterior (SUNARP 2004).

Los representantes de esta teoría de la nulidad no consideran este supuesto y confunden la validez con la eficacia. Si este negocio se considera inválido, no se puede confirmar. Por ende, sería ineficaz. Lo que significa que, si se declarase nulo, ya no se podría confirmar debido a que la invalidez es incorregible (Montiel 2003, 94-95). La tesis de la nulidad, a nuestro parecer, pretende atacar la validez del negocio que desde su formación es válido puesto que cumple con los requisitos establecidos en el ordenamiento jurídico peruano que lo dota de validez, además de que este negocio no contraviene los valores que inspiran el sistema normativo nacional. El negocio jurídico de disposición unilateral de bienes de la sociedad matrimonial tiene una declaración de voluntad libre y negocial que proviene de un agente capaz debido, es decir, ambas partes contratantes, el falso procurador y el tercero, fijan los términos que les serán vinculantes en el negocio en ejercicio libre de su autonomía de la voluntad, tiene un objeto física y jurídicamente posible, que en este caso es el bien, tiene un fin lícito que es el propósito práctico común (Taboada 1988, 74-75) que le hayan fijado las partes y en su defecto la causa típica (Betti 2000, 344-345), finalmente, se respeta la forma prescrita establecida por la ley o por las partes, de requerirse.

Como se puede apreciar, el negocio de disposición de bienes es perfectamente válido desde su constitución, por ende, a nuestro entender, un negocio bajo estas características y que cumple los requisitos de validez, no puede ser declarado nulo. Por lo tanto, el negocio es existente y es válido y no sufre de patología alguna que lo haga inválido.

La nulidad por otra parte lesiona injustificadamente los eventuales intereses del consorte que desconoce de la disposición realizada por su cónyuge de ratificar el acto realizado por este último si le importa beneficios a su esfera jurídica. La nulidad no permite otorgarles a los cónyuges no participes la ventaja de hacer el acto eficaz en su persona por los eventuales beneficios que este negocio le genere. Al ser la nulidad un remedio jurídico fulminante, extingue tanto el negocio como sus efectos negociales del acuerdo de disposición unilateral de bienes de forma perenne.
El falso representante que dispone de una cosa social a través del contrato transferencia de bienes realiza un negocio jurídico válido, pero ineficaz (Morales 2016, 310-311). Al ser válido el negocio no incurre en ninguna de las causales de invalidez de los negocios jurídicos establecidas en el Código Civil. Por consiguiente, no es idóneo tratar con una consecuencia jurídica distinta, como es la nulidad, que responde frente a la presencia de una patología en la validez de un negocio y que tiene sus propias causales, a un negocio que adolece de una patología en su eficacia con causales muy diferente a las de nulidad.

Un tratamiento jurídico de nulidad no se le puede dar a un negocio que adolece de un defecto en su eficacia debido a que no sería una consecuencia jurídica congruente ya que se estaría combinando los planos de perfección de todo negocio jurídico. En esa línea, como se ha visto, la falta de un poder que faculte a la representación configura una causal de ineficacia por falta de legitimidad para obrar, por lo tanto, no es correcto atribuirle consecuencias jurídicas de la nulidad.

\subsection{En la jurisprudencia}

La nulidad ha sido tomada en cuenta al momento de solucionar controversias que se han producido respecto a la disposición unilateral de bienes sociales. La máxima referencia en nuestra interpretación judicial son el Pleno Jurisdiccional Nacional de Familia, realizado en Cajamarca en el año de 1998 y el IV Pleno Jurisdiccional Civil Nacional y Procesal Civil que se realizó en Arequipa en octubre de 2015, los cuales acordaron y resolvieron que la consecuencia jurídica para los negocios de disposición unilateral de bienes de la sociedad conyugal es la nulidad.

El Acuerdo $\mathrm{N}^{\circ} 6$ del Pleno Jurisdiccional Nacional de Familia de 1998 establece en su segundo considerando (CSJR 1998) del Acuerdo $\mathrm{N}^{\circ} 6$ lo siguiente: 
Marja Vargas

“6.1. ¿Qué consecuencia tiene la disposición unilateral de bienes en la sociedad conyugal?

(...) 2.- Que, si contraviniendo dicha norma ${ }^{(18)}$ se practicara actos de disposición de bienes sociales por uno sólo de los cónyuges se incurriría en la causal de nulidad de acto jurídico prevista en el artículo doscientos diecinueve incisos uno del Código Civil, por falta de manifestación de voluntad de los titulares del dominio del bien y por ser contrario a las leyes que interesan al orden público según artículo Quinto del Título Preliminar del Código Civil.

\section{(...) El Pleno: por unanimidad acuerda:}

Que, los actos de disposición unilateral de los bienes sociales, inmuebles o muebles registrables o de derechos y acciones, que pueda hacer uno de los cónyuges sin la intervención del otro, es un acto jurídico nulo (...).”

De igual manera, diecisiete años más tarde, los Magistrados Supremos volvieron a fallar en el mismo sentido, resolviendo el Tema N² (CSJR 2017) del IV Pleno Jurisdiccional Nacional Civil y Procesal Civil, con 49 votos a favor y 45 en contra que propugnaban por la ineficacia del negocio (CSJR 2017), en que la nulidad era el remedio jurídico más idóneo frente a un supuesto de disposición unilateral de bienes sociales.

"El Acto Jurídico celebrado sin poder

En el caso de un acto de disposición de un bien de la sociedad de gananciales (bien social), por uno de los cónyuges sin intervención del otro, ¿el acto jurídico celebrado sin poder es nulo o ineficaz? (...)

\section{(...) 4. Conclusión Plenaria}

Es nulo. En los actos jurídicos en los que uno de los cónyuges dispone de bienes de la sociedad de gananciales sin la intervención del otro se advierte la falta del requisito de la manifestación de voluntad del cónyuge preterido en la celebración del acto, siendo la manifestación de voluntad un elemento primordial para su validez (inciso 1 del artículo 219 del Código Civil). El objeto del acto es jurídicamente imposible, toda vez que la ley establece que para disponer de bienes de la sociedad de gananciales se necesita el consentimiento de ambos cónyuges (artículo 315 del Código Civil). Finalmente, el acto jurídico podría contener un fin ilícito, pues existiría la voluntad de engañar y perjudicar al cónyuge que no interviene en dicho acto jurídico (...)."

Adicionalmente, unos claros ejemplos en donde apreciamos la tendencia de las Salas Civiles de la Corte Suprema a sentenciar en pro de la nulidad los encontramos en las casaciones emitidas en esta última década.

1. Casación $\mathrm{N}^{\circ}$ 336-2006-Lima (Diario Oficial El Peruano 2007)

“(..) Cuarto.- Que, en tal virtud, para disponer bienes sociales o gravarlos, se requiere la intervención del marido y la mujer, salvo que uno de ellos de poder al otro para ese efecto, de acuerdo al artículo trescientos quince del Código Civil, por lo que están prohibidos los actos de disposición unilateral de bienes inmuebles o los bienes muebles registrables sin intervención de ambos cónyuges; de modo tal que sí, contraviniendo dicha norma, se practica actos de disposición de bienes sociales por uno solo de los cónyuges se incurra en la causal de nulidad absoluta de acto jurídico prevista en el artículo doscientos diecinueve inciso primero del Código Civil, por falta de manifestación de voluntad de los titulares del dominio del bien y por ser contrario a las leyes que interesan el orden público según el artículo V del Título Preliminar del Código Civil (...)."

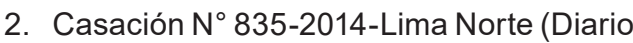
Oficial El Peruano 2015)

(18) Art. 315 del Código Civil. 
El tratamiento jurídico de la ineficacia en la disposición unilateral de bienes de la sociedad conyugal a puertas del Octavo Pleno Casatorio Civil

The legal treatment of inefficiency in the unilateral disposition of goods in the marital partnership at the gates of the Eighth Civil Cassation Plenaries

“(...) Décimo Cuarto.- Que, estando a lo señalado y teniendo en cuenta que el mencionado vendedor se encontraba casado con la demandante desde el diecisiete de setiembre de mil novecientos setenta, conforme se verifica del certificado de matrimonio de fojas tres, el acto jurídico cuestionado deviene en nulo, por la falta de intervención de la demandante en su celebración, pues el citado bien inmueble pertenecía a la sociedad conyugal conformada por la demandante (...)y el codemandado (...), es decir, se trataba de un bien social que solo podía ser enajenado con la intervención de ambos cónyuges; por lo tanto, al no haberse celebrado el contrato privado de compraventa de fecha dieciséis de mayo de dos mil con la intervención de ambos cónyuges, conforme lo dispone el artículo $315^{\circ} \mathrm{del}$ Código Civil, dicho acto jurídico es nulo. (...)."

3. Casación N³468-2007-Moquegua (Diario Oficial El Peruano 2009)

“(..)Décimo Primero.- Que, por consiguiente, al tratarse en el presente proceso de un patrimonio de naturaleza indivisible, no se puede decir de ningún modo que los efectos de nulidad del acto jurídico, por ausencia de manifestación de voluntad, de la actora, hayan de surtir efecto sólo con respecto a la demandante y no sobre el resto de las partes intervinientes, si se tiene en cuenta que los actos de disposición unilateral de los bienes sociales, inmuebles, que pueda hacer uno de los cónyuges sin la intervención del otro, es un acto jurídico nulo (...)."

\section{La tesis de la ineficacia como remedio jurídico conveniente a puertas del Octavo Plano Casatorio}

La teoría de la ineficacia, tesis que está empezando a ganar mayor aceptación (SUNARP 2016) dentro de la doctrina y la jurisprudencia, y que fue representada en las participaciones (La Ley 2015) de los amicus curiae por Rómulo Morales Hervias, Giovanni Priori Posada, Enrique Varsi Rospigliosi y Gastón Fernández Cruz, parte sus postulados indicando la diferencia entre ineficacia e invalidez. Para ellos, la ineficacia es el no surtimiento de efectos jurídicos esperados por las partes, lo que no implica invalidez (Husman 1993, 159-160). En el desarrollo de sus planteamientos en aras de aclarar la consecuencia adecuada para la disposición unilateral de bienes sociales, los defensores de la ineficacia nos introducen una nueva idea. Ellos plantean que, de una lectura completa del artículo $315^{\circ}$, se entiende que el supuesto que regula este mandato imperativo es uno por el cual uno de los consortes dispone o grava un bien de la sociedad conyugal sin que haya participado el otro. Sin embargo, una lectura detenida de la hipótesis de hechos nos revela que la norma no indica el momento en que ambos cónyuges deben intervenir manifestando su voluntad, ni exige que estas manifestaciones se realicen al mismo tiempo. Como dato relevante, el ordenamiento excluye de la concurrencia de ambas manifestaciones de voluntad si uno de los esposos tiene un poder especial expreso de su consorte para poder obrar en representación de la sociedad de gananciales que ambos conforman (Artículo $315^{\circ}$ del Código Civil).

De un análisis concordado del Código Civil, caemos en cuenta que nos encontramos en este supuesto de brete jurídico originado por la falta de legitimidad en la representación causado por parte del cónyuge que dispone de bienes. Ello debe entenderse de la siguiente manera; el consorte, al no poseer dicha legitimidad por carecer de poder de representación de la sociedad matrimonial, de realizar un acto de disposición sobre bienes sociales, su acto negocial se constituye como uno celebrado con ausencia de representación, que, de acuerdo al artículo $161^{\circ}$ del Código Civil ${ }^{(19)}$, si bien el negocio celebrado es válido

(19) Art 161 del Código Civil. - "El acto jurídico celebrado por el representante excediendo los límites de las facultades que se le hubiere conferido, o violándolas, es ineficaz con relación al representado, sin perjuicio de las responsabilidades que resulten frente a este y a terceros. También es ineficaz ante el supuesto representado el acto jurídico celebrado por persona que no tiene la representación que se atribuye." 
Marja Vargas

para el cónyuge que lo celebró, empero, este deviene en ineficaz para el cónyuge que ignora la realización de este negocio por su consorte.

A pesar de que, el cónyuge inocente, en función al artículo $162^{\circ} \mathrm{del}$ mismo texto legal ${ }^{(20)}$, tiene la opción de ratificar el acto si este le importa beneficios a su esfera jurídico-patrimonial. La actuación en nombre ajeno con desconocimiento del representado, como expuso Morales ${ }^{(21)}$, produce la consecuencia jurídica de ineficacia del acto realizado por atribuirse una representación de forma indebida, empero, ello no implica que el acto sea inválido, ya que, de serlo, el acto sería nulo e insubsanable y por ende no cabría la posibilidad de ratificarlo. No obstante, el ordenamiento mismo reconoce la validez del acto al permitir la eventual ratificación de este solo si quien realizó el acto de disposición actuó atribuyéndose facultades de representación que no le son debidas. Por lo tanto, es un supuesto de ineficacia por falta de legitimidad en la representación ya que no es un requisito de validez contemplado en nuestro ordenamiento jurídico civil.

Nosotros, al igual que el profesor Morales, comulgamos con los planteamientos ofrecidos por la doctrina de la ineficacia. A nuestro parecer, de una lectura integral de las normas que regulan el negocio jurídico en concordancia con el artículo $315^{\circ}$ del Código Civil, podemos deducir que la ley no exige como requisito para la validez del acto de disposición la intervención de ambos cónyuges. Ni las normas que regulan el acto jurídico ni el artículo en mención indican tal sentido. Lo que sí encontramos presente en este negocio realizado unilateralmente es un supuesto de falta de legitimidad pues quien celebra este acto no cuenta con un poder para disponer o gravar un bien de la sociedad, por lo cual, la sociedad no celebra ese negocio jurídico, es decir, no es parte de ningún contrato.

Repitiendo, un ejemplo claro de este supuesto ya mencionado de falta de legitimidad en la representación, éste lo encontramos en los supuestos de compraventa de bien ajeno. Frente a ello, el ordenamiento ha dispuesto que sean ineficaces (Morales $2007)^{(22)}$ respecto de quien es el propietario de ese bien, es decir, de quien posee el poder de disposición.

El supuesto que regula el artículo $315^{\circ}$ es similar debido a que quien posee ese poder de disposición es la sociedad conyugal, integrada y representada por ambos esposos, por lo tanto, el acto realizado por uno de los consortes a espaldas del otro es ineficaz por falta de legitimidad en la procuración y no nulo como cierto sector de la doctrina defiende. El negocio jurídico celebrado por uno de los esposos, en el caso del artículo $315^{\circ}$, posee los elementos constitutivos indispensables de validez debido a que ambas partes contratantes han manifestado su libre voluntad de celebrar el negocio jurídico, son sujetos con capacidad, existe tanto un objeto jurídicamente posible como un fin lícito ya que se pretende transferir la propiedad de un bien social sobre el cual quien realiza el acto también posee derechos de disponerlo como miembro integrante de la sociedad matrimonial que es parte junto a su consorte. Adicionalmente, al tratarse de un acto de disposición consensual realizado a través de un contrato de compraventa, en principio, no existe formalidad, pero si la hubiese y las partes la respetan, el negocio es perfectamente válido.

Pese a ello, el negocio jurídico válidamente realizado presenta una patología en el surgimiento de los efectos deseados por las partes, es decir, los efectos para los cuales fue

(20) Art 162 del Código Civil. - "En los casos previstos por el artículo 161, el acto jurídico puede ser ratificado por el representado observando la forma prescrita para su celebración. La ratificación tiene efecto retroactivo, pero queda a salvo el derecho de tercero. El tercero y el que hubiese celebrado el acto jurídico como representante podrán resolver el acto jurídico antes de la ratificación, sin perjuicio de la indemnización que corresponda. La facultad de ratificar se trasmite a los herederos."

(21) Vídeo de participación en el VIII Pleno Casatorio Civil de la Corte Suprema de la República la participación de los amicus curiae. Consulta: 27 de junio de 2017. <https://www.youtube.com/watch?v=E0e1cABGMNA>

(22) Art 161 del Código Civil. - "(...) violándolas, es ineficaz con relación al representado (...)." 


\section{El tratamiento jurídico de la ineficacia en la disposición unilateral de bienes de la sociedad conyugal a puertas del Octavo Pleno Casatorio Civil}

The legal treatment of inefficiency in the unilateral disposition of goods in the marital partnership at the gates of the Eighth Civil Cassation Plenaries

celebrado no se van a producir, al menos no provisionalmente. Esta patología es un defecto extrínseco (Palacios 2002, 91) al negocio, pero que repercute en él. Este defecto externo es la ilegitimidad de uno de los cónyuges para celebrar unilateralmente negocios jurídicos sobre bienes de la sociedad conyugal (Morales 2016, 310-320) ya que la legitimación para disponer de ese bien la tiene la sociedad como sujeto con patrimonio autónomo y no un solo esposo.

Según lo establecido en el artículo $292^{\circ}$ del Código Civil, al encontrarse la sociedad conyugal representada por ambos consortes conjuntamente y excepcionalmente por uno de ellos si existe un poder de representación conferido por el otro cónyuge. Si uno de los esposos realiza actos de disposición de bienes sociales sin la aceptación del otro, este se encontraría privado de la facultad de representación de la sociedad, que es la titular del bien, al no contar con dicha facultad conferida expresamente por su otro cónyuge. Por lo pronto, de transferirse el bien, se configuraría una ilegitimidad para negociar fundada en una falsa representación al carecer de facultades de representación respecto de la sociedad conyugal. Como consecuencia, el negocio realizado es válido, eficaz para el cónyuge que realizó el negocio, pero inoponible e ineficaz para el consorte que ignoraba el accionar de su cónyuge; ello en función a su actuar de buena fe (Espinoza 2017). Por ende, al ser válido e ineficaz el negocio, el cónyuge perjudicado tiene la opción de subsanar el acto realizado por su esposo confirmándolo de considerarlo conveniente. En caso de no ser ratificado, el cónyuge perjudicado puede pedir imprescriptiblemente (Espinoza 2015, 45) al juez que el acto no le sea oponible, es decir, dejarlo sin efecto en lo referente a su persona, en salvaguarda de los intereses de la sociedad conyugal, de la cual también es parte, pudiendo ejercer la acción reivindicatoria del bien social, como representante de la sociedad, en caso se le haya despojado del mismo y solicitarle al juez que lo declare propietario de ese bien social.

En consecuencia, como aporte lógico, cabe señalar que, si este negocio jurídico celebrado fuese nulo, desde su constitución habría nacido muerto y lo estará así para siempre ya que la nulidad por tener un defecto intrínseco grave en sus presupuestos de validez, como remedio declarativo del fenecimiento de un negocio, es insubsanable. Por lo tanto, no es posible que pueda ser ratificado por el cónyuge perjudicado si le produce beneficios ya que la nulidad no admite ratificación. Por lo expuesto, en el supuesto del artículo $315^{\circ}$ del Código
Civil nos encontramos frente a una patología extrínseca de los negocios jurídicos que es causal de ineficacia, tercer escalón de los negocios jurídicos, y no causal de invalidez como cierto sector de la doctrina alega, al confundir el segundo con el tercer escalón del análisis de los negocios jurídicos, siendo categorías jurídicas distintas con efectos distintos.

En ese sentido, consideramos que la tesis de la ineficacia es preferible con relación a la de la nulidad en función a que no solamente es la idónea desde un punto de vista jurídico, doctrinario y jurisprudencial, sino que se ajusta a la realidad jurídica de esta hipótesis de hecho que constantemente se presenta en nuestra sociedad, permitiendo la protección en el engranaje de nuestro sistema civil al cónyuge afectado y a la sociedad de gananciales, que es el sustrato patrimonial de la familia.

La jurisprudencia no es indiferente ante esta teoría de la ineficacia que cada vez cobra más fuerza entre los Jueces Supremos de la Salas Civiles, los cuales plasman en sus sentencias los planteamientos de quienes abogan por la idoneidad de la ineficacia como la consecuencia jurídica necesaria frente a actos de disposición unilateral de bienes sociales.

1. Casación N N 111-2006-Lambayeque (Diario Oficial El Peruano 2007)

“...) Tercero.- Que, tanto en la doctrina como en la jurisprudencia se ha discutido sobre el supuesto de hecho previsto en el artículo 315 del Código sustantivo, siendo que con esta Sentencia Suprema, se procede a variar criterios anteriormente establecidos, a fin de concluir que, el supuesto previsto en la referida norma no recoge un supuesto de nulidad del acto jurídico, sino uno de ineficacia, el mismo que origina que el acto jurídico 
Marja Vargas

cuestionado no sea oponible al patrimonio de la sociedad de gananciales (...).

(...) Quinto. - Es decir, la intervención de ambos cónyuges supone dar cumplimiento a un requisito de eficacia denominado legitimidad para contratar, el cual implica el "poder de disposición que tiene el sujeto con relación a una determinada situación jurídica” (...). Tal supuesto resulta plenamente reconocido por nuestro sistema jurídico, ya que el mismo puede ser encontrado también en el artículo 161 del Código Civil, a propósito de los efectos realizados por el denominado falsus procurator (...)."

2. Casación N 907-2008-Arequipa (CSJR 2008)

“(...) Octavo.- Que, aún más, las normas que regulan el acto jurídico no exigen como requisito para su validez la intervención de ambos cónyuges ni el artículo 315 del Código Civil se pronuncia en tal sentido, presentándose en el acto de disposición de uno de los cónyuges con exclusión del otro un supuesto de falta de legitimación, pues quien celebra el acto no goza del poder de disponer o gravar el bien, que es lo mismo que ocurre (falta de legitimación) en los casos de compraventa de bien ajeno, de modo tal que el acto celebrado no surtirá efecto - en línea de principio - respecto a quien sí goza de ese poder de disposición, para el caso del artículo 315, la sociedad conformada por ambos cónyuges, en relación a la cual el acto es ineficaz y no nulo, resultando oportuno señalar, no obstante, que la excepción puede presentarse en el caso del tercero registral al que refiere el artículo 2014 del Código Civil, cuyo derecho queda supeditado a la celebración del acto conforme a las exigencias que dicha norma establece (...)."

3. Casación N² 2893-2013-Lima (Diario Oficial El Peruano 2014)

“(...)5. En el caso del artículo $315^{\circ}$ del Código Civil es evidente que el acto jurídico cuenta con elementos constitutivos de validez, pues, ambas partes han manifiestan su voluntad de celebrar el acto jurídico, son agentes capaces, existe un fin lícito y un objeto jurídicamente posible porque se procura la transferencia de la propiedad de un bien sobre el cual el vendedor también ostenta derechos reales (como parte de la sociedad de gananciales que conforma) aunque no exclusivos $y$, finalmente, tratándose de un contrato de compraventa es netamente consensual, por lo que, no existe solemnidad que deba ser respetada. Por tanto, el acto jurídico de disposición cuenta con todos los elementos de constitución que lo hacen válido. Sin embargo, el acto jurídico debidamente constituido presenta un defecto extrínseco relevante, esto es, la ausencia de legitimación para contratar que ostenta el cónyuge celebrante respecto al bien social, porque la legitimación para disponer del bien es de la sociedad de gananciales como patrimonio autónomo y no de determinado cónyuge. Al respecto cabe precisar que según el artículo $292^{\circ}$ del Código Civil, la sociedad de gananciales se encuentra representada por ambos cónyuges (conjuntamente) y, de manera excepcional, por uno de ellos cuando existe poder del otro cónyuge para que aquel ejerza la representación total de la sociedad. Por tanto, es evidente que si uno de los cónyuges celebra un acto de disposición sin autorización del otro carecerá de facultades de representación expresas respecto al titular del bien, que es la sociedad de gananciales. Ergo, al celebrar el acto, el cónyuge culpable se atribuye una falsa representación. Por tanto, al carecer el enajenante de estas facultades de representación (respecto a la sociedad de gananciales) y de legitimidad para contratar, el acto jurídico es ineficaz e inoponible respecto del cónyuge inocente, quien, de creerlo conveniente podría confirmar el acto jurídico (...)."

La jurisprudencia de esta última década y pasada, pese a ser diversa, nos deja entrever la preferencia por los Magistrados Civiles por la ineficacia como una herramienta jurídica perfectamente adecuada y conveniente, no solo por la consistencia de los argumentos doctrinarios, sino porque esta se ajusta a la 
El tratamiento jurídico de la ineficacia en la disposición unilateral de bienes de la sociedad conyugal a puertas del Octavo Pleno Casatorio Civil The legal treatment of inefficiency in the unilateral disposition of goods in the marital partnership at the gates of the Eighth Civil Cassation Plenaries

realidad jurídica para resolver el problema que durante más de treintaitrés años no ha tenido una solución semejante entre los casos que se han presentado a conocimiento de los Jueces Supremos Civiles del Perú.

Es menester acotar que, al pretender uniformizarse la jurisprudencia, lo que primordialmente se desea realizar es zanjar la discusión doctrinaria y jurisprudencial que durante más de una década ha generado tanta inseguridad jurídica dentro de nuestro sistema normativo y judicial. La ineficacia, a nuestro entender, es el remedio jurídico apropiado para este negocio jurídico unilateral válido puesto que permite atacar los efectos prácticos del mismo al hacerlo inoponible al cónyuge ignorante de los actos que realiza su consorte, quien puede solicitar al juez que lo declare ineficaz en cualquier momento dado que esta es imprescriptible por falta de legitimidad para contratar, así como le podría dar la oportunidad al consorte perjudicado de ratificar el negocio realizado si este le provee beneficios, es decir, le es conveniente. Por ende, la ineficacia es el único remedio posible y adecuado a aplicar para actos de disposición de bienes en los que quien dispone carece de legitimidad para contratar. Este es el supuesto que recoge el artículo $315^{\circ}$ del Código Civil y la ineficacia su tan necesario efecto jurídico.

A modo de resumen, la ineficacia es el remedio que el ordenamiento jurídico civil prevé de una lectura integral de todo su cuerpo normativo frente a este tipo de actos unilaterales de disposición de bienes sociales, asegurando la consecuencia jurídica idónea frente a actos de esta naturaleza, configurando un costo que debe ser asumido por la sociedad a fin de tutelar a los consortes que no participaron titulares de su situación jurídica dispuesta, proveyendo una ventaja a la sociedad conyugal en aras de garantizar una protección inmediata de la familia

\section{Conclusiones}

- Acorde al temario del VIII Pleno Casatorio Civil, concluimos que la ineficacia en sentido estricto sería el manto jurídico protector del consorte lesionado no interviniente en el negocio jurídico de disposición de bienes sociales y, por ende, la consecuencia jurídica idónea al artículo $315^{\circ}$ del Código Civil, cuya falencia ha originado que nuestros jueces resuelvan en sus sentencias de manera tan diversa y contradictoria.
- De las doctrinas analizadas, debemos hacer hincapié que aún existen posturas en las que se confunde invalidez con ineficacia. Empero, en función a lo trabajado en esta investigación, debemos diferenciar a invalidez como el estado jurídico en que no hay acto jurídico. En cambio, en la ineficacia sí existe acto jurídico, empero, no produce los deseos aspirados. A partir de ello, es posible la comprensión del desarrollo garantista del interés familiar sobre el que se basa este trabajo.

- La ineficacia sirve como garantía y protección de la integridad patrimonial de la sociedad de gananciales que es el sustrato económico de la institución familia al permitirle a la familia mantener intacto su patrimonio frente a situaciones irregulares por las que pueda atravesar frente a actos de disposición realizadas por un de los integrantes de la sociedad familiar.

- Los jueces de las Salas Civiles Supremas, en su preocupación de unificar criterios de solución jurídica han realizado sesiones con juristas expertos en la materia en donde se han expuesto las dos principales teorías que resuelven a su entender el conflicto con el fin de contribuir a aclarar las dudas que los Supremos tengan con respecto a la aplicación del artículo $315^{\circ}$ y cuya decisión será emitida en el VIII Pleno Casatorio.

- Las tesis que han sido materia de discusión ante el pleno son la nulidad y la ineficacia, las cuales tienen naturaleza y consecuencias jurídicas totalmente distintas al encontrase en planos diferentes del negocio jurídico. Cabe destacar que la nulidad se produce de la invalidez de un negocio jurídico, mientras que la ineficacia se origina producto de la una patología sobrevenida a un negocio valido. 
Marja Vargas

- La falta de legitimad en la representación que realiza uno de los cónyuges configura un supuesto de ineficacia por ser una patología jurídica extrínseca a la estructura de un negocio válido. Al haber ilegitimidad de representación, el negocio celebrado por uno de los consortes deviene en ineficaz y es inoponible al cónyuge no participante.

- Es menester, de igual forma, hacer alusión al interés familiar - pilar fundamental de este trabajo- el cual se sobrepone al interés individual de sus integrantes y a las relaciones con terceros que la sociedad pueda tener, puesto que, tiene el firme propósito de salvaguardar el núcleo esencial de la sociedad, protegiendo a la familia en todo momento para que pueda realizar sus fines en su integridad contando con un respaldo económico que garantice su pleno sostenimiento.

- Bajo la óptica defensora de la familia, si bien se podría alegar que la nulidad es el remedio jurídico indicado que se debe aplicar cuando se realiza la disposición de un bien social sin la participación del otro consorte, siendo, su consecuencia jurídica, que el bien continúe siendo social para el beneficio de la familia, consideramos que la ineficacia permite que el otro cónyuge tenga la posibilidad de corregir el acto, dejándolo a este último en mejores condiciones de decidir si desea realizar la disposición o no, evitando que caiga en un desamparo jurídico, garantizado la igualdad de condiciones de los cónyuges en los actos de disposición social. Cabe resaltar que la familia está integrada no solo por el transferente, el cónyuge afectado, sino también por los hijos que crecen dentro de ella, siendo todos estos miembros aquellos que el ordenamiento jurídico también debe proteger; lo que a nuestro entender y en concordancia con lo explicado en el cuerpo del texto, se lograría con la aplicaría del remedio jurídico de la ineficacia.

- Conviene finalizar que, si bien el concepto de interés familiar es uno sobre el que hay un desconocimiento acerca de su significado y los efectos jurídicos proteccionistas que este despliega; éste interés, a nuestro juicio, es real y se manifiesta a través de las normas que se dan en beneficio de la familia y, es precisamente bajo el amparo de este interés que, la ineficacia es el mejor remedio jurídico que tutela los interés de la familia en su plenitud, garantizando su sustentabilidad y fortaleciéndola como unidad más esencial que protege el Derecho en su esencia, garantizando así la vida en comunidad.

\section{Referencias Bibliográficas}

Albaladejo, Manuel. 1958. El Negocio Jurídico. Barcelona: Librería Bash.

Betti, Emilio.2000. Teoría general del negocio jurídico. Traducción y concordancias con el Derecho español por Antonio Martín Pérez $y$ estudio preliminar por José Luis Monereo Pérez. Granada: Editorial Comares.

Bullard, Alfredo. 1993. El Derecho Civil peruano: perspectivas y problemas actuales. Lima: Fondo Editorial de la Pontificia Universidad Católica del Perú.

Canales, Claudia. 2007. Diálogo con la Jurisprudencia 108 (febrero): 99-104

Castillo, Mario y Martín, Pierre. 2002. Tratado de la Teoría General de los Contratos: La plena vigencia del Código Civil en la contratación contemporánea. Volumen XX. Biblioteca Para Leer el Código Civil. Lima: Fondo Editorial de la Pontificia Universidad Católica del Perú.

Corte Suprema de Justicia de la República. Pleno Jurisdiccional Nacional de Familia de 1998. http://historico.pj.gob.pe/CorteSuprema/ cij/documentos/Pleno_Jur_Nac_1998.pdf (Consultado el 01 de julio de 2017 ).

Corte Suprema de Justicia de la República, Casación N 3333-99-Junín (...) Derecho del conyugue sobre la sociedad conyugal como parte integrante de ella. (...) En el patrimonio autónomo la titularidad y la calidad de parte material recae en una entidad jurídica distinta a quienes la integran (...). Publicado en el Diario Oficial El Peruano el 17 de setiembre de 2000. 
El tratamiento jurídico de la ineficacia en la disposición unilateral de bienes de la sociedad conyugal a puertas del Octavo Pleno Casatorio Civil The legal treatment of inefficiency in the unilateral disposition of goods in the marital partnership at the gates of the Eighth Civil Cassation Plenaries

Corte Suprema de Justicia de la República, Casación № 3362006-Lima. Publicado en el Diario Oficial El Peruano el 1 de febrero de 2007.Considerando Primero.

Corte Suprema de Justicia de la República, Casación $N^{\circ}$ 3006-2015-Junín cuya pretensión en debate es la Nulidad de Acto Jurídico. Publicado en el Diario Oficial El Peruano de fecha martes 22 de diciembre de 2015.

Corte Suprema de Justicia de la República, Casación $\mathrm{N}^{\circ}$ 3006-2015-Junín (...) Tercero.- Que, entre los expedientes elevados en casación ante este Supremo Tribunal, se ha advertido que, de forma continua y reiterada, los diversos órganos jurisdiccionales del país, incluidas las salas civiles de este Supremo Tribunal, en los casos de actos de disposición de bienes de la sociedad de gananciales por uno de los cónyuges sin la intervención del otro, están resolviéndolos con criterios distintos y hasta contradictorios, señalando en algunas oportunidades que se tratan de actos jurídicos nulos y en otros de actos jurídicos ineficaces (...).

Corte Suprema de Justicia de la República, Tema $N^{\circ}$ 2 del IV Pleno Jurisdiccional Nacional Civil y Procesal Civil. 2017. 10- 15 https://www.pj.gob.pe/wps/wcm/ connect/d35de5804a47b1dc9d0dfd7f091476ed/ Nacional+civil+y+procesal+civil+arequipapdf?MOD=AJPERES \&CACHEID $=d 35$ de5804a47b1dc9d0dfd7f091476ed (Consultado el 5 de Julio de 2017).

Corte Suprema de Justicia de la República, Casación $N^{\circ}$ 907-2008-Arequipa. Publicado en el Diario Oficial El Peruano el 01 de diciembre de 2008.

De Castro, Federico. 1985. El Negocio Jurídico. Reedición de la $2^{\circ}$ reimpresión de la edición original de 1971. Madrid: Editorial Civitas.

De La Puente, Manuel. 1999. La sociedad de gananciales. IUS ET VERITAS 18 (junio): 52-55.

Defensoría del Pueblo. El amicus curiae-expresión latina que se puede traducir como "amigo del Tribunal"- es un informe escrito que puede ser presentado por una persona natural o jurídica que, a pesar de no tener un interés directo en el caso, interviene en él para defender un interés de trascendencia general, como cuando está en juego la defensa de los derechos fundamentales. El amicus curiae ¿Qué es y para qué sirve? Jurisprudencia y labor de la Defensoría del Pueblo, Serie Documentos Defensoriales. Documento 8 (Lima, 2009).

Diario Oficial El Peruano con fecha 31 de enero del 2007.

Diario Oficial El Peruano con fecha $1 \mathrm{de}$ febrero de 2007. Fundamento Jurídico $4^{\circ}$.

Diario Oficial El Peruano con fecha 30 de noviembre de 2009. Fundamento Jurídico $\mathrm{N}^{\circ} 11$.

Diario Oficial El Peruano con fecha 30 de mayo 2014.

Diario Oficial El Peruano con fecha 30 de setiembre de 2015. Fundamento Jurídico N 14.

Diario Oficial El Peruano con fecha 4 de diciembre de 2015.

Diario Oficial El Peruano con fecha 28 de diciembre de 2015, http://www.elperuano. com.pe/noticia-fijaran-criterio-sobre-actojuridico-36848.aspx (Consultado el 22 de junio de 2017).

Espinoza, Juan. 2001. Derecho de las Personas. Edición $\mathrm{N}^{\circ} 3$. Lima: Editorial Huallaga.

Espinoza, Juan. 2008. Acto jurídico negocial: análisis doctrinario, legislativo y jurisprudencial. Lima: Editorial Gaceta Jurídica.

Espinoza, Juan. 2015. ¿Prescripción de la pretensión de ineficacia ex artículo $161^{\circ}$ del Código Civil? Diálogo con la Jurisprudencia 200 (mayo): 41-45.

Espinoza, Juan. El principio de la buena fe. El autor dice lo siguiente: "(...) La buena fe es definida como una exigencia ético-social que 
Marja Vargas

está compuesta por el respeto de la personalidad ajena y por la colaboración con los demás (...).", http://www.academia. edu/8031826/EL_PRINCIPIO_DE_LA_BUENA_FE_JUAN_ESPINOZA_ESPINOZA (Consultado el 22 de julio de 2017).

García Sayán, Francisco. 2005. El acto jurídico según el Código Civil peruano: curso teórico, histórico y comparativo. Lima: Fondo Editorial de la Pontificia Universidad Católica del Perú.

Moisset de Espanés, Luis. Ponencia: bienes de los menores (Actos de administración y actos de disposición) Primera Jornada Notarial de Córdoba (Villa María 17, 18 y 29 de agosto de 1972), http://www.acaderc.org.ar/doctrina/articulos/bienesde-los-menores-actos-de-administracion-y/at_download/file. 1-2 (Consultado el 15 de julio de 2017).

Montiel, José. 2003. La invalidez del acto jurídico (ineficacia para la dogmática). Revista Jurídica de la Escuela Libre de Derecho de Puebla $4^{\circ}$ (diciembre): 91-104.

Morales, Rómulo. 2005. Contrato inválido. Revista Derecho PUCP 58 (MMV): 101-129.

Morales, Rómulo. 2007. Nuevas perspectivas del Negocio Jurídico. Revista Derecho y Sociedad. Edición 28 (XVIII):293-306.

Morales, Rómulo. Nulidad e inoponibilidad del contrato vs. El principio de la fe pública registral de fecha 09 de junio de 2007. El autor dice: "(...) negocio ineficaz que fue celebrado por el representante sin poderes (...).", http://moraleshervias. blogspot.pe/2007/06/nulidad-e-inoponibilidad-del-contrato. html (Consultado el 18 de julio de 2017).

Morales, Rómulo. 2011. Patologías y Remedios del Contrato. Lima: Jurista Editores.

Morales, Rómulo.2013. La falta de legitimidad en los contratos inoponibles. Actualidad Jurídica 230 (enero): 13-21.

Morales, Rómulo. 2016. La falta de legitimidad del contrato: inoponibilidad o ratificación. Diálogo con la Jurisprudencia 208 (enero): 309-332.
Jara, Rebeca y Gallegos, Yolanda. 2011. Manual de Derecho de Familia. Lima: Jurista Editores.

La Ley. 2005. Acto unilateral de disposición de bienes sociales: ¿nulidad o ineficacia? Lo que dijeron los amicus curiae en el VIII Pleno Casatorio Civil. En portal jurídico "La Ley", http://laley.pe/not/2995/lo-que-dijeron-losamicus-curiae-en-el-viii-pleno-casatorio-civil/ (Consultado el 30 de junio de 2017).

León Hilario, Leysser. 2014. El Negocio Jurídico, Introducción al Régimen General de los Negocios Jurídicos en el Código Civil peruano. Lazarte Zabarburu, Marina (Coord.), Lima: M. J. Bustamante De la Fuente.

Palacios, Eric, 2002. La nulidad del negocio jurídico: principios generales y su aplicación práctica. Lima: Jurista Editores.

Plácido, Álex. 2005. Administración común del patrimonio social en Código Civil Comentado tomo II. Derecho de Familia (Primera parte). Lima: Gaceta Jurídica.

Pontes de Miranda, Francisco. 1954. Tratado de direito privado - Parte geral, $2^{\circ}$ Edición. Rio de Janeiro: Borsoi. (Citado en página 50 por León, Leysser.2014. El Negocio Jurídico, Introducción al Régimen General de los Negocios Jurídicos en el Código Civil peruano. Lazarte Zabarburú, Marina (Coord.), Lima: M. J. Bustamante De la Fuente.)

Pozo, Julio. 2016. VIII Pleno Casatorio Civil: venta del bien social por un solo cónyuge. Lima: Universidad Nacional Mayor de San Marcos.

Roppo, Vincenzo. 2009. El contrato. Traducción de Nélvar Carreteros Torres y de Eugenia Ariano Deho, Lima: Gaceta Jurídica. 
El tratamiento jurídico de la ineficacia en la disposición unilateral de bienes de la sociedad conyugal a puertas del Octavo Pleno Casatorio Civil The legal treatment of inefficiency in the unilateral disposition of goods in the marital partnership at the gates of the Eighth Civil Cassation Plenaries

Rubio, Marcial. 2003. Nulidad y Anulabilidad. La Invalidez del Acto Jurídico, Edición $\mathrm{N}^{\circ}$ 6. Lima: Fondo Editorial de la Pontificia Universidad Católica del Perú.

Savigny, Friedrich. 1878. Sistema de Derecho Romano Actual. Traducido del alemán al francés por Charles Guenoux y traducido al español por Jacinto Mesía y Manuel Poley. Prólogo de Manuel Durán y Bas. Madrid: F. Góngora y Compañía Editores. https://doi. org/10.5771/9783845234588-21

Sconamiglio, Renato. 2004. Contribución a la Teoría del Negocio Jurídico. Edición, traducción y notas de Leysser L. León. Prólogo de Pietro Rescigno. Lima: Editorial Grijley.

Stolfi, Giusseppe. 1959. Teoría del negocio jurídico. Traducción y notas del Derecho español de Jaime Santos Briz. Madrid: Editorial Revista de Derecho Privado.

Superintendencia Nacional de los Registros Públicos. Resolución N 192-2004-SUNARPTR-Arequipa. 22/11/04, Jurisprudencia Registral, San Marcos. Tomo I. 692. (...) Facultades para disponer de bienes o derechos de la sociedad conyugal. Conforme lo señala el artículo $315^{\circ}$ del Código Civil, para disponer de los bienes sociales o gravarlos se requiere la intervención del marido y la mujer, lo que no significa que la voluntad sea necesariamente manifestada en un solo acto, pudiendo hacerse mediante acto complementario celebrado en momento y lugar diferente, por lo que siendo ello un requisito subsanable, no procede la tacha sustantiva, sino la observación del título respectivo (....)."

Superintendencia Nacional de los Registros Públicos. ¿Nulo, anulable o ineficaz?: A propósito del VIII pleno Casatorio civil. Aula Registral en Línea- SUNARP, https://aurelia.sunarp.gob. $\mathrm{pe} / \mathrm{local} / \mathrm{blog} /$ nulo-anulable-o-ineficaz-a-proposito-del-viiipleno-casatorio-civil/ (Consultado el 30 de junio de 2017).

Taboada, Lizardo. 1988. Comentarios al Código Civil: causales de nulidad del acto jurídico. Thémis 11 (junio): 71-76.

Taboada, Lizardo. 1992. La problemática del objeto del negocio jurídico en la dogmática jurídica moderna y la necesidad de unificar la noción de objeto del contrato y del acto jurídico dentro del Código Civil peruano. IUS ET VERITAS 5 (noviembre): 53-60.

Taboada, Lizardo. 2002. Acto jurídico, negocio jurídico y contrato. Lima: Editorial Grijley.

Vásquez, Walter. Los actos de disposición de bienes sociales por parte de uno de los cónyuges. Argumentos adicionales a favor de la tesis pro-ineficacia ad-portas del Octavo Pleno Casatorio Civil, http://enfoquederecho.com/civil/ determinacion-del-objeto-de-la-compraventa-inmobiliariao-relevancia-de-la-clausula-ad-corpus-comentario-a-unareciente-resolucion-de-la-corte-suprema-2/ (Consulta: 30 de junio de 2017).

Zegarra, Álvaro. 2009. Descubrir el derecho: las nociones elementales del Derecho Privado y del Derecho Público explicadas en forma sistemática. Lima: Palestra Editores.

Zusman, Shoschana. 1993. Teoría de la invalidez y la ineficacia. IUS ET VERITAS 7 (noviembre): 159-167. 